\title{
"SPIDER LICK" $"$ \\ AN EPIDEMIC OPHTHALMO-DERMATOZOOSIS DUE TO BEETLES OF THE GENUS PAEDERUS
}

\author{
BY
}

\section{E. J. SOMERSET \\ Calcutta, India}

IN certain parts of the world and at certain seasons, a number of patients may be seen who show lesions of a character which at once strike one as being unusual and not described in textbooks of ophthalmology, nor in standard student textbooks of medicine, dermatology or tropical medicine. One has only to see a few cases to realize that here are lesions so characteristic as to constitute a syndrome. The lesions may be seen on any part of the exposed skin, but are especially common on the eyelids and contiguous skin of the face, so that patients sometimes present themselves initially at a hospital eye department or to an ophthalmic surgeon. Far more cases, however, are seen by general practitioners. The clinical appearance is that of a reaction to some insect or toxic plant, so that calamine lotion or some antibiotic cream is prescribed, and the condition heals in about a week to 10 days. The trivial nature of the condition is probably the reason for the omission of an adequate description in most textbooks, and for the fact that its aetiology is not generally known. In the north-eastern region of India, where the condition is comparatively common, it is called "spider lick", but it is not due to a spider nor caused by a lick.

\section{Symptoms and Signs}

A patient usually says that he awoke a few days previously with a slightly sore and swollen area on one side of the face, often including the eyelids. Similar sore areas may also be found on the neck and forearms, and occasionally on other parts of the body. The pain and swelling increase during the next 2 days and may be quite severe sometimes sufficiently to cause the patient to cease work. He usually gives no history of injury, nor of contact with an insect, but occasionally a more detailed history can be obtained.

Case 1.-The patient stated that at about 9 o'clock one morning he felt an insect in the region of his right eye. He brushed it off with his hand and at the time felt only a faint tickling sensation on the face. That evening his lower lid was slightly red. The

* Received for publication July $25,1960$. 
following morning it was swollen and by the evening ( 36 hours after the insect attack) there was considerable redness, swelling, and pain. The next day (after 48 hours) he showed the typical picture of "spider lick" (Fig. 1).

Case 2.-While driving in a car one morning in Assam, the patient felt some insect hit him near the left eye. There were no symptoms then or the next day, but the following morning (after 48 hours) he awoke with very sore left lids and cheek, and when seen that day he showed the typical clinical appearance of "spider lick".

On examination a number of red linear weals up to $1^{\prime \prime}$ long and $\frac{1}{4}$ broad may be seen (Fig. 1). In the centre of each weal is a narrow yellowish line, which on magnification looks as though the surface cells had been splashed by some coagulating fluid. The surrounding skin is oedematous. The lesion is tender to touch. Vesiculation is not generally seen, but the yellowish lines sometimes look like a row of tiny coagulated vesicles. The local lymph gland is seldom enlarged and there is no fever or symptoms of general toxaemia. The conjunctiva and cornea usually escape, but occasionally intense conjunctival congestion is seen (Fig. 2), and even more rarely part of the corneal epithelium is found to be denuded and stains with fluorescein.

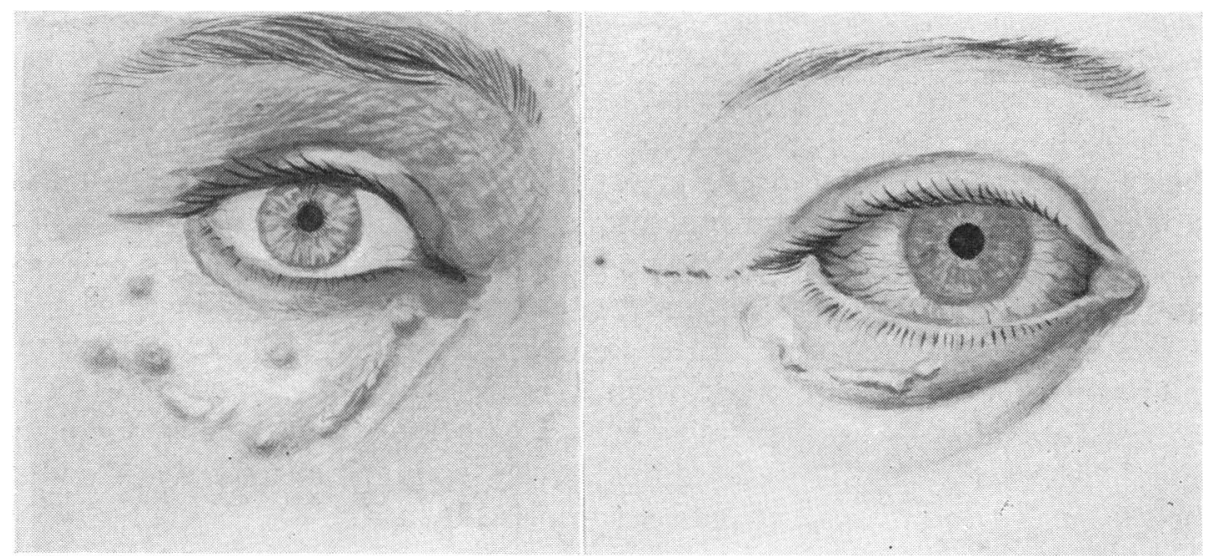

FIG. 1.-Case 1, showing typical lesions of the eye lids.
FIG. 2.-Lesions of the lids, with conjunctival involvement.

\section{Diagnosis}

The clinical condition once seen is easily recognized again. The swollen area of skin containing the weals is very characteristic, and the central yellowish line of coagulated surface cells is pathognomonic. In mild cases this line is not well seen except under magnification.

The following are other conditions which constitute the differential diagnosis.

(1) The secretions of other vesicant beetles of the family Meloidae (Cantharidae), the principal genera being Epicauta, Lytta (Spanish fly), and Mylabris (Chinese blister beetle), produce large dermal bullae after 12 to 24 hours. The blisters are dome-shaped $\frac{1}{2}$ " to $1^{\prime \prime}$ in diameter, circumscribed, more or less round, and contain much clear straw-coloured fluid (Fig. 3, opposite). 


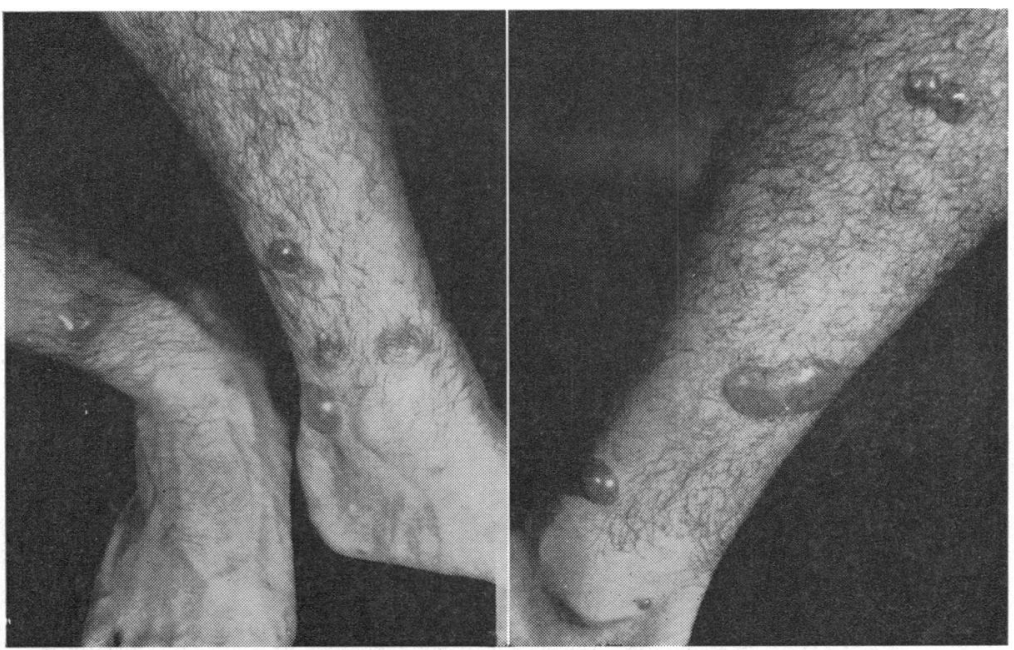

FIG. 3.-Bullae, due to blister beetles of the family Memoidae (after Swarts and Wanamaker, 1946).

(2) The bites of mosquitoes, flies, and midges produce a painless localized circular area of oedema in the centre of which may sometimes be seen the red mark of the bite.

(3) Ant stings are painful at the moment of stinging and produce a localized area of oedema with a very definite sting mark in the centre.

(4) The sudden agonizing pain at the time of the sting of bees, wasps, and hornets and the recognition of the insect are unmistakable.

(5) Spider bites and scorpion stings are similar in clinical manifestation to bee and wasp stings but the general symptoms are more marked.

(6) Bites by bed bugs and fleas cause small red papules on the skin accompanied by scratch marks from the patient's nails and are found usually on the thorax and abdomen.

(7) With tick bites the tick is usually found attached to the skin, and the reaction is very slight.

(8) In caterpillar dermatitis caused by urticating hairs, the caterpillar is usually found by the patient. Red weals but no vesiculation are produced, and the hairs may be found on the skin.

(9) With leech bites, the leech is almost always found firmly attached to the skin in the process of gorging itself with blood. The tiny puncture mark bleeds freely.

(10) A history of sudden pain while bathing in the sea will always be obtained with lesions due to jelly fish stings.

(11) The hot, red, slightly raised skin with a spreading margin is characteristic of erysipelas.

\section{Treatment}

Secondary infection may be prevented by a sulphathiazole or antibiotic ointment, though an antihistamine cream such as 'Caladryl' is perhaps more soothing. In severe cases antihistamine tablets by mouth for a few days are beneficial. The occurrence of conjunctivitis will necessitate saline lotion irrigation several times daily. Involvement of the cornea will require atropine and a pad. 
Complications.-The only complication of consequence is secondary infection. This is dealt with by the local application or injection of suitable antibiotics.

\section{Aetiology}

According to Castellani and Chalmers (1919), beetles have been known to cause blisters of the skin since the days of Archigenes, a contemporary of Celsus, and perhaps since the time of Aretaeus the Cappadocian. Pliny noted that authorities differed as to the origin of the blistering fluid, some supposing that it came from the mouth and others from the feet. Although Beauregard (1890) wrote a book entitled "Les insectes vesicants", works on tropical medicine were singularly silent on the subject.

Vorderman (1901) was the first to record in medical literature a dermatitis caused by beetles of the genus Paederus, which occurred at Anjer-Kidoel on the Sunda Straits and at Raoen near Djember in Java. The species $P$. peregrinus (Fabricius) recorded by Vorderman is, however, often regarded as only a variety of $P$. fuscipes, and it was in fact first described not by Fabricius but by Erichson, fuscipes being the older name of the species (Bequaert, 1959). Pirajá da Silva (1912), who is given the credit of the first description by many subsequent authors, described an outbreak of dermatitis in Brazil which was due to $P$. columbinus; this outbreak occurred amongst cultivators on the banks of the rivers Saõ Francisco, Itapicuru, and Jacuricy in the interior of Bahia. Eysell (1913) gave $P$. peregrinus (Erichson) as the cause in the Sunda Islands in the Malay Archipelago, and Rodhain and Houssiau (1915) and Bequaert (1921) described cases in the Belgian Congo due to $P$. sabaeus (Erichson). Bequaert noted that Goeldi (1913) mentioned that another species from Brazil, $P$. goeldii (Wasmann), also had irritant properties. Epidemics of dermatitis due to $P$. fuscipes (Curtis) on the banks of the Volga delta were recorded by Sacharov (1916) and Portchinsky (1915), and Netolitzky (1919) noted that the beetles were used by the local peasants to produce simulated ulcers of the skin. Ross (1916) described an epidemic in Nairobi showing identical lesions to those described by Rodhain and Houssiau, and known locally as "Nairobi Eye". He described the experience of a doctor who was lying in bed when a beetle flew in, hit the wall, dropped on his forehead, and walked across it. He brushed it off and next day there was a bright vesicular streak as if the forehead had been stroked with a brush containing strong acid. The beetle was identified as $P$. crebrepunctatus (Eppelsheim). An interesting paper by Strickland (1924) on "Spider Lick", as the condition is called in India, records that a Mr. Duff, an employee of Messrs. Bird \& Co., Calcutta, who was residing in the state of Orissa, suspected that the condition was due not to a spider but to some other insect. He actually caught an insect, subsequently identified as $\boldsymbol{P}$. fuscipes, and placed it together with a "flying ant" under an upturned glass. A great fight ensued and the ant was laid out, the knock-out appearing 
to have been administered by the tail of the Paederus beetle. Until this observation the Paederus beetle had not been associated with "Spider Lick" in India, local folk-lore attributing it to the urine of a lizard (Elliot, 1920).

Cases due to $P$. sabaeus were described from Sierra Leone by Gordon (1925), who noted that similar lesions were to be seen at Manaos, Amazonas, in Brazil at all seasons. The insect $P$. amazonicus is known to the local inhabitants as "Poto". P. irritans, a new species described by Chapin (1926), and P. ornaticornis (Campos, 1927) were found to be the cause of epidemics of typical lesions in Ecuador. Other epidemics due to $P$. signaticornis and $P$. laetus in Guatemala were reported by Bequaert $(1932,1938)$, and Genevray, Gaschen, Autret, and Dodero (1934) described epidemics due to $P$. fuscipes and $P$. alternans in Tonkin. Cases have also been described from the Argentine by Dallas (1930), from Japan by Matsunaga (1923), Itô (1932), and Esaki (1933), and from Taiwan by Miyamoto (1934) and Kanda (1935). Further cases from Nairobi due to P. crebrepunctatus were described by Symes and Roberts (1934) and Roberts and Tonking (1935), and small epidemics in Italy were reported by Baccaredda (1935) and Castelli (1935). The last-named mentioned a case investigated by Prof. Niccolato of Pavia in which the typical lesions on the skin of the face were associated with a beetle in the conjunctival sac which was identified as $P$. fuscipes, so that cause and effect were evident. Further cases due to $P$. ferus (Erichs) and $P$. braziliensis (Erichs) from Brazil were recorded by Pickel (1940), while epidemics of this dermatozoosis which occurred in May, June, and July in Bangalore, India, due to P. melampus (Erichs) were described by Pujatti (1947). Other observations of the vesicant properties of these beetles have been recorded by Degorge and Bablet (1913), Gladin (1928), Genner (1929), Andresen (1931), Baba (1939), Baliña (1939), Huse (1939), Kaminsky (1939), Yoshihiro (1940), Rojas (1943), Allard (1948), and Théodorides (1950). Table I (overleaf) lists those species of Paederus which are known to have caused dermatitis in nature, and Table II (overleaf) shows additional species which have caused dermatitis in experiments only. Both Tables are derived from Bequaert (1959).

\section{Beetles of the Genus Paederus}

The earth is inhabited by a vast number of insects, and it has been estimated that two acres, which are reputed to support one human family and a cow, contain some eight million insects. About 652,000 kinds of insects have been described and there are probably between 2 and 4 million different species (Kennedy, 1949). The class Insecta is divided into about 25 orders, beetles forming the order Coleoptera, which contains about 250,000 described species, more than any other order from Protozoa to Vertebrata. Coleoptera are divided into about 154 families, and two of these are of medical 
TABLE I (Personal communication, Bequaert, 1959)

SPECIES KNOWN TO HAVE CAUSED DERMATITIS IN NATURE

\begin{tabular}{|c|c|c|c|c|}
\hline \multicolumn{3}{|l|}{ Species } & \multirow{2}{*}{$\begin{array}{l}\text { First Description } \\
\text { Walker }\end{array}$} & \multirow{2}{*}{$\begin{array}{l}\text { Place of Observation } \\
\text { Tonkin }\end{array}$} \\
\hline P. alternans $\quad$.. & .. & .. & & \\
\hline P. amazonicus .. & .. & .. & Sharp & Brazil \\
\hline P. brasiliensis .. & .. &.. & Erichson & Brazil, Argentina \\
\hline P. columbinus .. & .. & .. & Laporte de Castelnau & Brazil \\
\hline P. crebrepunctatus & .. & .. & Eppelsheim & Kenya \\
\hline P. ferus &.. &.. & Erichson & Brazil, Argentina \\
\hline P. fuscipes $\ddagger \S$.. & .. & .. & Curtis & $\begin{array}{l}\text { Russia, India, Tonkin, Japan, } \\
\text { Taiwan }\end{array}$ \\
\hline P. goeldii $\uparrow$ &.. &.. & Wasmann & Brazil \\
\hline P. irritans & .. & .. & Chapin & Ecuador \\
\hline P. laetus & .. & .. & Erichson & Guatemala \\
\hline P. melampus .. & .. &.. & Erichson & India \\
\hline P. ornaticornis .. & . & .. & Sharp & Ecuador \\
\hline$P$. parallelus .. &.. &. & Weise & Japan \\
\hline P. peregrinus* & .. & .. & Erichson & Java \\
\hline$P$. poweri & .. &.. & Sharp & Japan \\
\hline P. sabaeus &.. &.. & Erichson & Congo, Sierra Leone \\
\hline P. signaticornis & .. & .. & Sharp & Guatemala \\
\hline
\end{tabular}

* Regarded as a variety of $P$. fuscipes.

$\dagger$ Apparently an undescribed species.

$\mp$ Synonym P. idae (Sharp).

$\$$ Misidentified as $P$. riparius, which does not occur in Japan, by Wada (1926).

interest; the Meloidae include the genera Epicauta (blister beetle), Lytta (Spanish fly), and Mylabris (Chinese blister beetle), and the Staphylinidae, popularly known as rove-beetles or devil's coachmen, contains amongst many others the genus Paederus with which we are now concerned. There are at least 250 known species of Paederus beetles, most of which contain vesicating fluids (Patton, 1929). Cameron (1931), in describing the 43 species of the genus Paederus recorded in the Indian peninsula, notes that, to the nonentomologist, most of them look alike, but there are very slight differences in colour, and under suitable magnification slight differences in the shape and structure of the head and thorax can be made out. 
TABLE II (after Bequaert, 1959)

ADDITIONAL SPECIES KNOWN TO HAVE CAUSED EXPERIMENTAL LESIONS

\begin{tabular}{|c|c|c|c|c|}
\hline \multicolumn{2}{|l|}{ Species } & First Description & Author & Date \\
\hline P. albipilis $\quad$. & $\ldots$ & Solsky & $\begin{array}{l}\text { Pavlovsky and Stein } \\
\text { Andresen }\end{array}$ & $\begin{array}{l}1928 \\
1931\end{array}$ \\
\hline P. littoralis $\quad$.. & .. & Gravenhorst & $\begin{array}{l}\text { Allard } \\
\text { Theodorides }\end{array}$ & $\begin{array}{l}1948 \\
1950\end{array}$ \\
\hline P. limnophilus.. & $\begin{array}{ll}\ldots & \ldots\end{array}$ & Erichson & Netolitsky & 1919 \\
\hline$P$. riparius & .. & Linnaeus & Theodorides & 1950 \\
\hline P. ruficollis* .. & .. & Fabricius & Netolitsky & 1919 \\
\hline P. rubrothoracicus & .. $\quad \ldots$ & Goeze & Theodorides & 1950 \\
\hline
\end{tabular}

Note.-Some of the species known to have caused dermatitis in nature, as listed in Table I, have also been the subject of experiments.

Synonym: P. gemmelus (Kraatz).

Isaac (1933, 1934) gives the following description of $P$. fuscipes (Fig. 4):

P. fuscipes (Curtis) is found in many parts of the world, including Europe, North and Central Africa, Asia, and Indonesia. The original description of the species by Curtis (1826) was from a specimen found in the New Forest near Brockenhurst, England. The beetle breeds in damp porous soil, rich in decaying matter, along the banks of rivers, irrigation channels, drains, and pools, a few inches above the edge of the water. Several pairs in copulation may be found here during certain seasons, crawling about or hiding in fissures or cracks and under leaves.

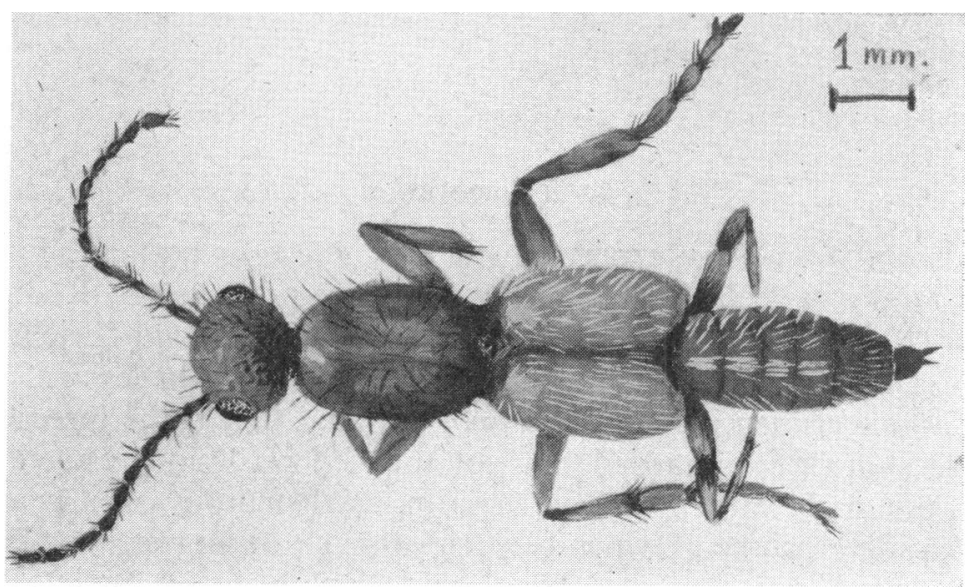

FIG. 4.-Paederus fuscipes. Actual size about $7 \mathrm{~mm}$. long. 
The egg is spherical, light brown, and $0.7 \mathrm{~mm}$. in diameter, with a leathery pitted surface.

The larva on hatching is $1.7 \mathrm{~mm}$. long and is shiny slaty-brown in colour. The abdomen shows ten distinct segments, the ninth carrying a pair of chitinous incurved single-jointed cerci. When full-grown it is moderately active, grey in colour, and $4.7 \mathrm{~mm}$. long. The whole body is setaceous and the two-jointed cerci are very long.

The pupa has no sort of protective covering, is free and $3 \mathrm{~mm}$. long. The head is bent downwards and held close to the thorax. It is white in colour when newly formed, and slowly changes to creamy yellow with an orange tinge in all the abdominal segments except the last two. The adult is a small insect, only about $7 \mathrm{~mm}$. long (Fig. 4). It has a blue-black head, dull orange thorax, short dark-blue shiny elytra, a dull orange abdomen ending in a blue-black tip. The elytra, under which the membranous lower wings are folded, are short and allow much of the abdomen to be exposed, giving the beetles an appearance somewhat similar to that of earwigs. It is easily mistaken for an ant. The male and female adults can be distinguished by examining the ventral surface of the abdomen. In the female the sixth sternite is entire, but in the male the corresponding sternite has a narrow medium excision.

Life-History and Larval Moults. - The eggs are laid singly in the soil about an inch below the surface. Each female beetle lays about six eggs every day for several days. The larva remains in the soil, feeds on decaying matter and also preys on tadpoles and Syrphid larvae. It moults twice and at the third instar becomes fully-grown, remains quiescent in its usual habitat, moults, and changes into the pupa. The life-cycle is, egg 2 to 3 days, larva about 7 days, and pupa 3 to 4 days. The larvae and pupae are preyed on by soil mites and Carabid larvae.

\section{Experimentation}

Various observers have experimented with Paederus beetles. Erythematous and mildly vesicular lesions of the skin were produced by Rodhain and Houssaiu (1915), and Netolitsky (1919), using $P$. limnophilus (Erichson) and $P$. gemellus (Kraatz), produced similar experimental skin lesions. Strickland (1924) experimenting with $P$. fuscipes, found that if the insect crawled across the skin or was harried but not touched no lesion resulted; when, however, the insect was rubbed on the arm, erythematous papules appeared some 2 days later, some of which became vesicular during the next 24 hours. A similar lesion was produced by painting an alcoholic extract of about twelve specimens of $P$. fuscipes on the skin of the arm; it took about 48 hours 
for the first erythema to appear and papules developed 24 hours later. Gordon (1925) produced experimental lesions on the skin with the thorax or abdomen but not with the head, and Pawlovsky and Stein (1927) found that the emulsion of $P$. fuscipes produced lesions when it was rubbed on the skin but not when it was only painted on. They isolated various organs of the beetle and found that skin reactions could be obtained with the male and female genital glands, but not with the stomach, hindgut, or anal glands. The blood, however, gave a more definite reaction. Roberts and Tonking (1935) repeated Strickland's experiments and noted the long delay of 24 to 48 hours between rubbing the skin with the beetle and the appearance of the lesion. They also produced the lesion with an alcoholic extract of the beetle. Similar experiments with similar findings were repeated by Isaac (1933), who also wrote up the insect's life history (Isaac, 1934).

Froes (1935), from his own experiments, concluded that the vesicating fluid was not emitted voluntarily by any special mechanism, but exuded from any part of the integument when the insect was pressed or crushed. Linear lesions were produced when the insect was rubbed across the skin and more circumscribed lesions when it was crushed against the skin, and experimental lesions could be produced by any part of the insect. Experiments by Castelli (1935) showed that, by squeezing the abdomen, a bead of yellowish substance could be made to exude from the secretory gland opening on the pygidium or last abdominal segment, which was intensely irritating to the conjunctiva. Conjunctival irritation could also be produced by the separated head, thorax, or abdomen of the insect. Similar experiments with similar results were also recorded from Italy by Baccaredda (1935), who related that a patient, suffering from the condition, gave an accurate description of an encounter with an insect. From this description Baccaredda was able to collect some insects, identify them as $P$. fuscipes, and produce typical skin lesions. He concluded that the noxious substance came mainly from the pygidial glands but that other parts were also irritating.

An interesting observation by a patient (Nodder, 1956) shows that the excretion on the skin may be transferred by contact to another area of the skin. She wrote "... woke in the morning to find all the soreness and angry redness of a pattern of "spider lick" on the inner surface of the arm above the elbow. But I had been sleeping with my arm doubled up and the pattern of "spider lick" was repeated in a mirror image on the inner surface of my arm below the elbow. The secondary 'licks' were almost, but not quite, as sore and red as the original ones".

Personal Experiences.-My own experience is that cases can occur in and around Calcutta at almost any time of the year, but are particularly common from February to June. A specimen, later identified as $P$. fuscipes, was caught by me one evening and held by the head and thorax while the end of the abdomen was rubbed firmly across the anterior surface of the forearm. 
There was no discomfort at the time and no reaction till about 48 hours later, but during the next 18 hours a typical lesion appeared (Fig. 5).

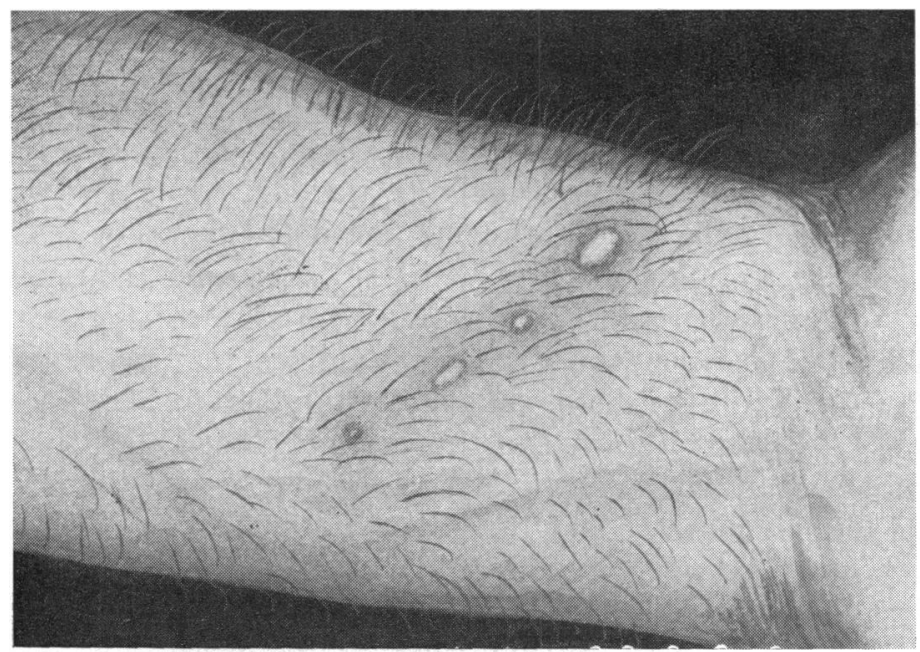

Fig. 5.-Experimental lesions on the author's forearm.

Another specimen of $P$. fuscipes was washed first in ether and then in water, and then cut with scissors into five parts-head, thorax, upper and lower abdomen, and terminal tip. The scissors were carefully cleaned between each cut to prevent the transference of noxious fluid from one part to another. Each part was now firmly rubbed on a portion of skin. No reaction was obtained with the head; a faint reaction resulted from the thorax, upper abdomen, and terminal tip; a severe reaction was obtained with the lower portion of the abdomen. The reactions began to appear after 24 hours and were at their maximum after 48 hours.

On another occasion a specimen of $P$. fuscipes was caught and held very lightly by the head. The body was very gently and slowly wiped several times across a portion of the writer's skin. There was no pressure and no squeezing of the insect and the skin was only lightly touched, but 36 hours later an erythema appeared which in the course of the next 24 hours developed into typical lesions with the characteristic central yellowish linear coagulation.

\section{Nature of the Vesicating Substance}

The nature of the noxious excretion is not known. Cantharadin has been suggested by Roberts and Tonking (1935) but this is unlikely. Wada (1926), in Japan, where ground-up beetles are used as an indigenous counter-irritant, experimented with extracts from $P$. riparius and found that it was soluble in chloroform, ether, benzol, alcohol, and oil, but relatively insoluble in 
distilled water. He isolated the substance and obtained a residue of colourless needle-shaped crystals. He was unable to identify the substance but concluded that it was not cantharadin. He failed to induce immunity to the substance in rabbits. He considered the toxic substance to be distributed throughout the body of the insect and not concentrated in any gland or glands. Pawlovsky and Stein (1928) found that the alcoholic extract from $P$. fuscipes was heat stable to $100^{\circ} \mathrm{C}$. They compared the effects of lesions from Paederus extract with those produced by cantharadin. The latter showed a main reaction round the skin follicles with the formation of papules and pustules, while the former produced papules away from the follicles. On histological grounds, therefore, they concluded that the noxious substance was not cantharadin. Netolitsky (1919) also concluded that it was not cantharadin but a member of a group of phlogotoxins. Castelli (1935) found that the noxious substance was chemically stable even after several months. At present the nature of the vesicating substance is unknown.

\section{Discussion}

It seems that there is no doubt that beetles of the genus Paederus are the cause of this characteristic dermatozoosis, and that the skin manifestations take one or two days to appear, and are sufficiently characteristic to be distinguished from any other condition. We have seen that all parts of the insect probably contain the noxious substance, presumably in the haemolymph, and that some observers consider that the lesions result only if the beetle is crushed. This however cannot be so; my clinical cases and experiments and the observations of the medical practitioner quoted by Ross (1916) clearly indicate that, when merely annoyed, the insect squirts a noxious substance on to the skin. That this may be so is suggested by the fact that beetles of several families including Staphylinidae emit, according to Phisalix (1922), from their posterior extremities acrid products as a defensive mechanism. Various paired glands (named pygidial glands by Dierckx (1899) from their situation in the last abdominal segment or pygidium) possibly throw out a noxious fluid. Strickland (1924) noted that the last abdominal segment in $P$. fuscipes was very mobile, and that the terminal tip of the abdomen could be bent over so as almost to touch the dorsal surface. It seems, therefore, likely on clinical and anatomical grounds that the haemolymph in all parts of the insect is toxic but that a noxious substance is also forcibly excreted by the insect as a defence mechanism.

\section{Summary}

The symptoms, signs, diagnosis and treatment of "spider lick", an epidemic ophthalmo-dermatozoosis, are described. 
The condition is due to irritation by secretions of beetles of the genus Paederus.

The literature is reviewed. Credit for the original description of this condition should go to Vorderman, who first observed it in Java in 1901.

Most parts of the insect seem to contain an irritant substance, but in all probability the lesions are normally produced by active secretion from glands near the hinder end of the insect as a defence mechanism.

A short description of $P$. fuscipes is given.

I wish to express my gratitude to Dr. Joseph C. Bequaert, Department of Biology, University of Houston, and late of Harvard, Mass., for lending me reprints of many articles, for the two tables, and for help without which this paper would not have been possible. I also wish to thank Dr. P. Sen, Department of Entomology, School of Tropical Medicine, Calcutta, for identifying beetles, Fr. Doro for help with translations, and Mrs. D. H. P. Henderson for finding and collecting beetles.

\section{REFERENCES}

Allard, V. (1948). Thèse, Paris. "Les staphylinides vésicants du genre Paederus. Étude entomologique. Rôle pathogène". Foulon, Paris.

ANDRESEN, E. (1931). Mag. Parasitol. Musée zool. Acad. Sci. U.S.S.R., 2, 151 [in Russian, with German summary]. (Quoted by Bequaert, 1959.)

BABA, K. (1939). Kontyû (Tokyo), 13, 242 [in Japanese]. (Quoted by Bequaert, 1959.)

BACCAREDDA, A. (1935). G. ital. Derm. Sif., 76, 1423.

BALIÑA, P. P. (1939). Rev. argent. Dermatosif., 23, 522.

BEAUREGARD, H. (1890). "Les insectes vésicants." Alcan, Paris. (Quoted by Castellani and Chalmers, 1919, p. 2204.)

Bequaert, J. (1921). Ann. Soc. belg. Méd. Trop., 1, 227. (1932). Bull. Brooklyn ent. Soc., 27, 107.

(1938). In "A Medical Survey of the Republic of Guatemala", by G. C. Shattuck and others. Publ: Carnegie Institute, Washington, No. 499, p. 223. (1959). Personal communication.

CAMERON, M. (1931). "The Fauna of British India including Ceylon and Burma", vol. 2: Coleoptera. Staphylinidae, p. 38. Taylor and Francis, London.

Campos R, F. (1927). Rev. Col. Noc. Vicente Rocafuerte (Guayaguil), Ecuador, 9, Nos. 27-28, 227. (Cited by Bequaert, 1932, and Pickel, 1940.)

CAstellani, A., and Chalmers, A. J. (1919). "Manual of Tropical Medicine", 3rd ed. Baillière, Tindall and Cox, London.

Castelli, A. (1935). Ann. Ottal. Clin. Ocul., 63, 204, 241.

CHAPIN, E. A. (1926). Arch. Schiffs-u. Tropenhyg, 30, 369.

CURTIS, J. (1826). "British Entomology", vol. 3, Plate No. 108. (Quoted by Isaac, 1934.)

Dallas, E. D. (1930). V Reunione Soc. Árgentina Patologia Regione Norte, vol. 2, p. 163.

DEGORGE, A., and BABLET, V. (1926). Bull. Soc. med.-Chir. Indochine, 4, p. 446.

DIERCKX, F.' (1899). Zool. Anz., 22, 311. (Quoted by Phisalix, 1922.)

Ellot, R. H. (1920). "Tropical Ophthalmology", p. 139. Frowde: Hodder and Stoughton, London.

EsaKI, T. (1933). Honzo, Tokyo, 11, 27. (Quoted by Bequaert, 1959.)

EYSELL, A. (1913). "Handbuch der Tropenkrankheiten", vol. 1, p. 247. (Quoted by Gordon, 1925.)

Froes, H. P. (1935). J. Parasitol., 21, 124.

Genevray, J., Gaschen, H., Autret, M., and Dodero, J. (1934). Inst. Pasteur Indochine, No. 19, p. 313.

GenNER, V. (1929). Ann. Derm. Syph. (Paris), 10, 269. (Quoted by Bequaert, 1959.)

GLADIN, S. (1928). v. Graefes Arch. Ophthal., 120, 229.

GöLDI, E. A. (1913). "Die sanitarisch-pathologische Bedeutung der Insekten und verwandten Gliedertiere", p. 13. Friedländer, Berlin. (Quoted by Bequaert, 1921, and Netolitzky, 1919.)

Gordon, E. A. (1925). Ann. trop. Med Parasit., 19, 47.

HuSE, S. (1939). Jap. J. Derm. Urol., 45, 145. (Quoted by Bequaert).

IsAAC, P. V. (1933). Agriculture and Live-stock in India, 3, 33. (1934). Indian J. agric. Sci., 4, 200. 
ITo, Y. (1932). Fukuoka-Ikwadaigaku-Zasshi, 25, 60. (Quoted by Bequaert, 1959.)

KAMINSKY, A. (1939). Rev. argent. Dermatosif., 23, 578, 1939.

KANDA, K. (1935). Taiwan Igakkai-Zasshi, 34, 1013. (Quoted by Bequaert, 1959.)

KENNEDY, C. H. (1949). "Insects", Encyclopaedia Britannica.

MATSunAGA, T. (1923). Acta derm. (Kyoto), 2, 227. (Quoted by Bequaert.)

MIYAм0то, S. (1934). Taiwan Igakkai-Zasshi, 33, 901. [German summary, p. 97.] (Quoted by Bequaert, 1959.)

NetoltTZKY, F. (1919). Z . angewandte Entomologie, 5, 252.

NODDER, W. (1956). Personal communication.

PatTon, W. S. (1929). "Insects, Ticks, Mites and Venomous Animals of Medical and Veterinary Importance", pt. I, p. 701. Grubb, Croydon. (1931). Idem, Pt. II, p. 425.

Pawlovsky, E. N., and Stein, A. K. (1927). Arch. Schiffs-u. Tropenhyg., 31, 271. (1928). Z. Parasitenkunde, 1, 476.

Phisalix, M. (1922). “Animaux venimeux et venins", vol. 1, p. 447. Masson, Paris.

PiCkerel, D. B. (1940). Rev. Entomol. (Rio de J.), 11, 775.

PiRajá da Silva, M. (1912). Arch. Parasitol. (Paris), 15, 431.

Portchinsky, I. A. (1915). Ljubitel Prirody (Friend of Nature, Petrograd), No. 12, p. 364. (Quoted by Pawlovsky and Stein, 1927.)

PujatTi, D. (1947). Mem. Soc. entomol. ital., 26, 5.

RoberTs, J. I., and TonkING, H. D. (1935). Ann. trop. Med. Parasitol., 29, 415.

Rodhain, J., and Houssiau, J. (1915). Bull. Soc. Path. exot. (Paris), 8, 587.

RoJAS, R. R. (1943). Bol. Sanit. Guatemala, 14, 128.

Ross, P. H. (1916). J. trop. Med. Hyg., 19, 202.

SAKHAROV, N. (1916). "Rapport de" 1915 de la Station Entomologique d'Astrakhan" [in Russian]. (Quoted by Bequaert, 1932.)

STRICKLAND, C. (1924). Indian med. Gaz., 59, 385.

SwarTs, W. B., and Wanamaker, J. F. (1946). J. Amer. med. Ass., 131, 594.

Symes, C. B., and RoberTs, J. L. (1934). Rep. med. Res. Lab. Kenya, 21.

THÉODORIDES, J. (1950). Bull. Soc. Path. exot. (Paris), 43, 100.

VORDERMAN, A. G. (1901). Geneesk. T. Ned.-Ind., 41, 282. (Quoted by Bequaert, 1932.)

WADA, H. (1926). Jap. J. Derm. Urol., 26, 1044 [German summary, No. 11, p. 46].

Yoshiriro, I. (1940). Ibid., 47, 121. 